\title{
Language education policy in Nepal and the denial of the right to speak in Indigenous languages
}

Edition 7, 2021

Prem Phyak

DOI: 10.37839/MAR2652-550X7.7

Language education policy (LEP) in Nepal has historically been a contested issue. Reviewing documents relating to Nepal's LEP from the 1950s, I examine how Nepal's policy has misinterpreted multilingualism, constructing deficit views of Indigenous languages, popularly known as 'mother tongues', and violated the constitutional rights of Nepali communities to preserve and promote their language and culture.

\section{The historical construction of monolingualism}

Nepal's LEP is historically linked to the state's project of nationalism. Education for the masses was not accessible until 1951; and during the Rana regime (1854-1951) education for the public was perceived to be a threat to the ruling class. Toward the end of the Regime, some Bhāṣā Pāțhśālās (language schools) were established for the public which promoted Nepali as the medium of education. The modernisation of education through systematic policy change began after the fall of the Rana regime. Unfortunately, the subsequent LEPs embraced a monolingual ideology and reinforced monolingual nationalism.

The autocratic Panchayat regime (1960-1990), for example, embraced ek-desh-ek- 
bhaashaa (one-nation-one-language) ideology, which defined Nepali nationalism as a homogenous community of the people speaking the same language. Traditionally known as Parbate Kurā or Gorkhā Bhāșā, Nepali is the mother tongue of the rulers, mainly the Ranas and Shahs, and the dominant caste group, Khas-Arya. The Regime promoted Nepali as the sole official language and banned the use of Indigenous languages in schools, courts, and government offices.

A policy report of Nepal's National Education Planning Commission (NNEPC), written by US expert, Dr Hugh B. Wood, recommended the use of Nepali as the sole medium of instruction for schools and universities. Regarding mass education as way of strengthening 'nationalism', the Commission (1956) stated that Nepali should be the sole medium of instruction for school and tertiary education to develop its status as a 'true national language'. The Commission's report banned the use of the local mother tongues in school playground. It stated that giving space to local mother tongues in education would be counterproductive to the development of Nepali as a national language.

Founded on the ideology of nationalism as an imagined community of homogenous language speakers, the state's education policies had an integrationist approach to linguistically, ethnically, and culturally diverse communities; aiming to produce 'ideal' Nepali persons who speak one language (Nepali) and follow Hindu as the national religion. Textbooks, exam systems, teacher recruitment policies and curriculum development processes were all nationalised. In this process, the state, as Lava Deo Awasthi, Chairperson of the Language Commission, argues 'imported' Western language ideologies such as monolingualism and standard language ideology. Monolingual ideology in education not only reproduced the cultural and symbolic capital of Nepali, but also, and perhaps more importantly, reinforced the 'deficit ideology' of multilingualism and Indigenous languages. This ideology devalues the importance of multilingualism and considers Indigenous languages to be a problem in education.

Indigenous communities resisted the one-nation-one-language state policy by 
organising clandestine campaigns and literacy classes, even though the state restricted freedom of speech and activist activities before 1990 and policed, arrested, and punished Indigenous activists.

\section{Language rights and multilingualism in education after 1990}

Due to the People's Movement in 1990, a multiparty democratic regime was restored after 30 years, opening up political space for historically marginalised groups. The 1990 Constitution, recognised Nepal's linguistic, ethnic, and cultural diversity as part of the state's identity, and subsequent policy emphasised the need for mother tongue education, at least in words. However, the state could not address linguistic and cultural diversity in education, and instead promoted English as the medium of instruction through the privatisation of education.

Following the provisions of the Constitution, Indigenous communities and ethnic minorities formed their own organisations to collectively ensure the right to use their mother tongues in the public sphere. Under the leadership of the Nepal Federation of Indigenous Nationalities, Indigenous communities lobbied political parties and government and organised a series of street movements in support of education in mother tongues; to preserve and promote their cultures and lands; and to use their mother tongues for official purposes.

In 2006, there was another People's Movement that overthrew the long history of the monarchy and created more political space for Indigenous and marginalised communities. The Interim Constitution of 2007 guaranteed the right to use and obtain education in mother tongues. In 2015, the Constituent Assembly drafted and approved the Constitution of the Federal Democratic Republic of Nepal, which states that Nepal is a 'multilingual, multicultural, and multi-ethnic country.' Although the Constitution has not fully addressed the voices of Indigenous people, women, Madhesis, Dalits, and other marginalised groups, it includes multilingualism as the 
state's ideology and references to the right to use mother tongues in public spheres; as well as stating that citizens will not be discriminated against on the basis of their linguistic, cultural, ethnic, and religious backgrounds. The census has identified 123 languages and 125 different ethnic groups; and the government has recognised 59 communities as Indigenous peoples of Nepal with unique linguistic, cultural, and historical identities.

Nepal's Ministry of Education (MoE) has developed a number of policies and plans to implement these constitutional provisions. One of the major priorities is the mothertongue-based multilingual education (MTB-MLE) policy. With a goal to ensure access, equity, and quality in education, the MoE first piloted the MTB-MLE program in nine different languages (Athapariya, Santhali, Rajbangshi, Urau, Maithili, Rana Tharu, Magar, Nepali, and Tamang) in six districts in 2007-2009. The design of the program was informed by Indigenous epistemology, ecology, and place: the creation and implementation of plans; materials development and use; and classroom pedagogies based on local knowledge, cultures, history, and place. Teachers, parents, students, and other members of the community collaborated on ways to use local knowledge in the classroom. Despite some challenges, the program was considered an innovative, transformative and engaged approach to multilingual education, contributing to increased school attendance among minority communities and these students' meaningful participation in classroom activities.

The MTB-MLE was the first policy document that explicitly highlighted the use of mother tongues as a medium of instruction in schools. The policy articulates the need to use mother tongues as a medium of instruction for equitable and sustainable literacy and academic knowledge of the children from minoritised language communities.

In its School Sector Reform Plan (2007-2016) and School Sector Development Plan (2016-2023), the MoE also emphasised the use of mother tongues as a medium of instruction to ensure equitable and quality learning for all children. These plans have included the activities such as materials development, teacher training, and 
awareness-raising programs to implement the MTB-MLE policy.

In addition to the MTB-MLE, Nepal's government has produced numerous other expert reports, policies, and action plans for multilingual education. The report of Languages Policy Recommendation Commission (1994) was one of the country's first comprehensive language education policy documents and in some ways highlights the importance of mother tongues in education and the need for the preservation and promotion of minoritised languages. The Commission recommended education through 'mother tongues' and developed action plans for documentation and standardisation (for example, dictionary making, orthography development and textbook writing) in Indigenous languages.

However, the Commission was not clear about how multilingualism should be implemented in schools, and unfortunately, this well-intended policy reproduces a narrow monolingual ideology of language education. For example, the Commission recommends that:

'In the schools with a predominantly multilingual context, it would be appropriate to adopt the language of the nation [Nepali] as the medium of instruction.' (p.38)

This recommendation embraces a monolingual ideology which latently considers the use of multiple languages in education as a problem. It constructs and promotes a separatist language ideology which denies the use of multiple mother tongues in the same school. Indeed, the Commission recommends that mother tongue education is appropriate only in a 'monolingual area' where the majority of students speak the same mother tongue. In Nepal, most schools are bi-/multilingual. Although students may come from the same ethnic group, they are emergent bi-/multilinguals who learn Nepali and English as two mandatory languages at school. In this sense, the recommendation of the Commission embraces the essentialist language ideology which defines language-ethnicity relation as unified and bounded.

The national curriculum framework (2007) has highlighted the 'basic education in mother tongue' as one of the main principles of the school curriculum and stated 
that 'mother tongue' can be taught as a local subject. However, this framework also makes a provision that allows schools to teach subjects related to 'information and communication technology' and 'local communities' such as animal husbandry and poultry farming in lieu of mother tongues. As a result, most public schools have introduced information and communication technology subjects instead of teaching mother tongue.

\section{Unclear policies and very little implementation}

Despite being an effective educational program, the MTB-MLE policy has not been implemented in all mainstream schools. Rather than using 'mother tongues' as a medium of instruction, some schools are teaching them as a subject, and use Nepali and/or English as the medium of instruction. 


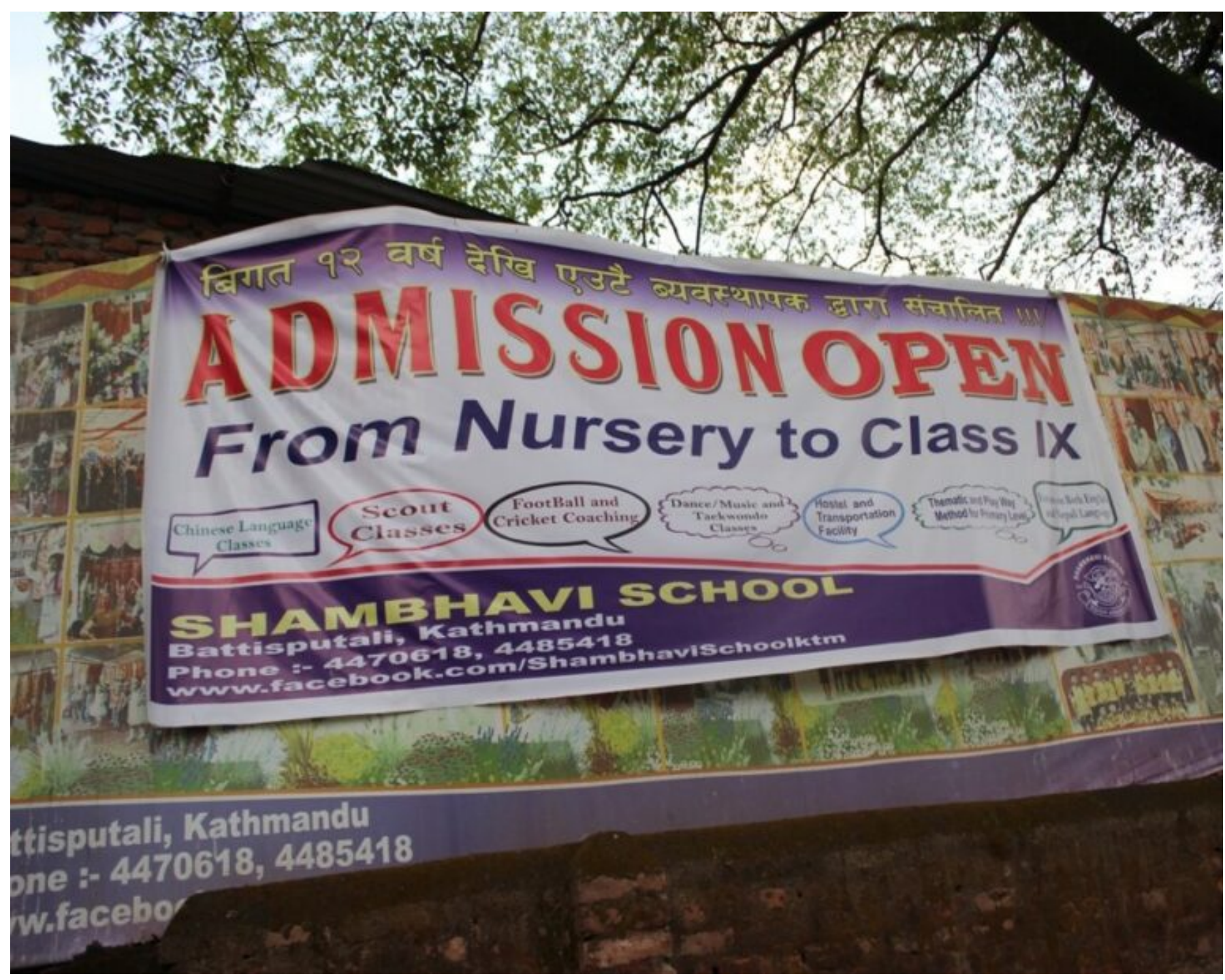

Advertisement of a private school in a public space of Kathmandu. Credit: Author

There are two main reasons for this. First, the policy is not mandatory for private schools that use English as a de facto medium of instruction and promote it as a symbol of quality education. Second, public schools have faced growing pressure to compete with private schools across the country. Parents and students are increasingly attracted to the private schools that use English as a medium of instruction, and as this trend increases, public schools are obliged to do the same. Although there is a lack of evidence that students have returned to public schools because of English as the medium of instruction, there is the assumption that 
English schools provide quality education.

The state's inconsistent ideologies in education policy have played a critical role in the dismissal of the use of mother tongues as a medium of instruction in schools. For example, the 2019 National Education Policy states that Nepali and mother tongues shall be the medium of instruction for the basic level of education. But this policy includes a new provision which creates unequal value between languages and strengthens the deficit ideology of mother tongues, questioning the relevance of the MITB-MLE policy. The provision states that 'STEM-Education' (Science, Technology, Engineering and Mathematics) will be a core component of the school curriculum and that these subjects can be taught in English from the early grades, which implies that mother tongues are not appropriate for teaching STEM subjects. This unequal treatment of languages in the MoE's policies supports English as the language of technological advancement and positions the relevance of mother tongues only for teaching local subjects.

Superficially, Nepal's present LEP policy seems to be inclusive as it gives space for Nepali, English, and mother tongues. But at the deeper level, this policy is ideologically charged. By legitimising the space of English as a medium language from the early grades, the policy embraces the ideology of English as a language of competitive and quality education. It also reinforces the perceived social, economic, and symbolic capitals of English in local and international contexts and positions the use of other languages as marginal.

The current situation is that Nepali is the de facto medium of instruction in the public schools while English is the de facto medium in private schools. Private schools rarely implement the MTB-MLE policy and therefore reinforce the deficit ideology of mother tongues in public discourse. This has contributed to social division between the graduates of English private schools and Nepali public schools. It has created the widespread view that public schools are less competitive and provide a lower quality education than private schools (which is exacerbated by the fact that private school students generally achieve higher scores in the national 
exams than students from public schools). As this view continues to influence language education policies, the Indigenous children's right to speak their mother tongue is compromised.

\section{The right to speak and the English medium obsession}

The place of English in Nepal's education landscape has remained the center since the beginning of formal education. Promoted as the language of bikās nationalism (development nationalism) in the 1960s, English has since been positioned as the marker of modernity, global mobility, and even quality education. As education in English becomes attractive to students and parents, public schools across the country are increasingly adopting it. The MoE has also revised its Education Act to state that the medium of education in school 'shall' be Nepali or English or both languages (and that the education up to primary level may be imparted in the mother tongue'). On the one hand, this policy promotes and legitimises the use of both English and Nepali as the major languages of education. On the other hand, rather than ensuring the right to speak mother tongues, the policy creates an unequal language hierarchy. In this regard, applied linguist Ruanni Tupas uses the term 'inequalities of multilingualism' to describe the similar situation in the postcolonial context of the Philippines where the sociopolitical and economic power of English is taken for granted and celebrated as a natural condition.

Studies have shown that English as a medium of instruction does not necessarily contribute to achieving the goal of English proficiency. In the context of Nepal, as a second and, for many students, a third language, English is the weakest language for many early grade students. As the findings from language education studies have shown, learning academic content through a weak language does not develop strong academic skills in that language. Second, the students cannot fully participate in pedagogical activities and invest their knowledge and identities in the entire learning process in English. 
English as a medium of instruction is falsely being presented, by schools and government officials (mostly at the local level), as a panacea to address the issue of decreasing student number in the public schools. This obsession with English as a medium of instruction (I am using this term to describe the glorification of EMI in the context where English is already a compulsory subject from the first grade) has become a core part of the discourse of educational reform and the development agenda of the government.

However, the implementation of English as a medium of instruction has raised some critical questions about its relevance in Nepal's multilingual schools. First, it reproduces the symbolic power of English as a global language and reinforces a deficit ideology of Indigenous and minoritised languages. To have a deficit ideology of languages is to embrace a deficit view about the speakers of those languages: in schools where English is a medium of instruction, both private and public, students who are not able to communicate in English are considered to be deficient in learning and not as 'good' as other students. These schools use different policing strategies such as posting signs stating 'English-speaking zone' on walls and punishing students for speaking languages other than English.

As the EMI policy is increasingly normalised, students' 'right to speak' in their home languages is violated. In Nepal, English is rarely used at home and in the community for everyday social interactions. As most students speak Nepali and other Indigenous/minority languages in real-life contexts, they feel comfortable communicating with their teachers and friends in these languages. However, many students are forced to use English-only at school, through prescribed English textbooks, EMI policy, and tests/exams being held in English. Studies have shown that students' participation in learning activities, particularly in the early grades, is not meaningful and equal; the students remain silent because they are not allowed to interact with their teachers and classmates in the languages other than English.

Students become less invested in the learning process and, more importantly, lose their right to speak as a multilingual citizens-supposedly a right guaranteed in the 
Constitution-because their identities as multilingual speakers are not recognised in schools where English is the medium of instruction.

Main image: Indigenous people's protest for their rights in front of the Constituent Assembly building in Kathmandu on May 16, 2012. Credit: Author. 